\title{
Pemodelan Indeks Pembangunan Manusia Dan Indeks Pembangunan Gender Di Indonesia Dengan Pendekatan Regresi Probit Biner Bivariat
}

\author{
Lendy Dinda Ayu Safitri ${ }^{*}$, Elvira Mustikawati Putri Hermanto ${ }^{2 *}$, Artanti \\ Indrasetianingsih ${ }^{*}$
}

\begin{abstract}
Indicators of success in building quality of life can be seen from the Human Development Index (HDI) and the Gender Development Index (HDI). Both of these indicators are able to be a benchmark of success and equity carried out by the government. Probit model regression is a model to explain the pattern of relationships of a categorical response variable. Bivariate binary probit model is a probit model involving two response variables, each of which has two categories. The predictor variables used in this study were the Number of Women Becoming Civil Servants, Percentage of High School Participation Rates / equivalent, Gross Regional Domestic Product (GRDP), and Percentage of Labor Force Participation Rate (TPAK). The results of the analysis conducted by the best model showed that 3 variables had a significant effect on HDI and IPG, namely the Number of Women Becoming Civil Servants, the Percentage of High School Participation Rates / equivalent, and Gross Regional Domestic Product (GRDP). There is an AIC value of 60,00768 with a classification accuracy obtained from the best model of 76.5 percent.
\end{abstract}

Keywords: Indeks Pembangunan Manusia (IPM), Indeks Pembangunan Gender (IPG), MLE, Regresi Probit Biner Bivariat, AIC.

\begin{abstract}
Abstrak
Indikator keberhasilan membangun kualitas hidup dapat dilihat dari Indeks Pembangunan Manusia (IPM) dan Indeks Pembangunan Gender (IPG). Kedua indikator tersebut mampu menjadi tolak ukur keberhasilan dan pemerataan yang dilakukan oleh pemerintah. Regresi model probit adalah suatu model untuk menjelaskan pola hubungan dari sebuah variabel respon yang bersifat kategorik. Model probit biner bivariat adalah model probit melibatkan dua variabel respon yang masing-masing mempunyai dua kategori. Variabel prediktor yang digunakan dalam penelitian ini adalah Jumlah Perempuan Menjadi PNS, Persentase Angka Partisipasi Sekolah SMA/sederajat, Produk Domestik Regional Bruto (PDRB), dan Persentase Tingkat Partisipasi Angkatan Kerja (TPAK). Hasil analisis yang dilakukan model terbaik didapatkan 3 variabel berpengaruh signifikan terhadap IPM dan IPG, yaitu Jumlah Perempuan Menjadi PNS, Persentase Angka Partisipasi Sekolah SMA/sederajat, dan Produk Domestik Regional Bruto (PDRB). Terdapat nilai AIC sebesar 60,00768 dengan ketepatan klasifikasi yang diperoleh dari model terbaik sebesar 76,5 persen.
\end{abstract}

Kata Kunci: Indeks Pembangunan Manusia (IPM), Indeks Pembangunan Gender (IPG), MLE, Regresi Probit Biner Bivariat, AIC

\section{Pendahuluan}

*Program Studi Statistika, Universitas PGRI Adi Buana Surabaya

Email : ${ }^{1}$ lendydinda@gmail.com, ${ }^{2}$ elvira@unipasby.ac.id, ${ }^{3}$ artanti.indra@unipasby.ac.id 


\section{Lendy Dinda Ayu Safitri, Elvira Mustikawati Putri Hermanto, Artanti Indrasetianingsih}

Indeks Pembangunan Manusia (IPM) dan Indeks Pembangunan Gender (IPG) merupakan dua jenis indikator yang umum dalam analisis capaian pembangunan suatu Negara/wilayah. IPM merupakan indikator penting untuk mengukur keberhasilan dalam upaya mambangun kualitas hidup manusia (masyarakat/penduduk). Analisis capaian pembangunan kualitas hidup di suatu wilayah dapat dilihat dari IPM, tetapi indikator tersebut belum mencerminkan disparitas gender yang sedang menjadi isu global, sehingga diperlukan IPG sebagai indikator pembangunan kualitas hidup dengan pembeda jenis kelamin untuk tiap komponen. IPG merupakan indeks pembangunan kualitas hidup manusia yang lebih menekankan status gender, sehingga keberhasilan pembangunan yang mengakomodasi persoalan gender dapat diukur.

Kedua indikator tersebut diperkenalkan oleh United Nation Development Programme (UNDP) pada tahun 1990 dan 1995. Laporan Human Development Report (HDR) tahun 2015 menyatakan bahwa IPM Indonesia berada diperingkat 110 dari 188 negara yaitu sebesar 68,38 pada level sedang dan berada di bawah rata-rata dunia $(71,05)$. Jika capaian IPM Indonesia masih di bawah rata-rata dunia, IPG nya sedikit di atas rata-rata. IPG yang dihitung oleh UNDP menunjukkan bahwa secara umum IPG dunia berada di kisaran 92,36 dan IPG Indonesia sebesar 92,74. Angka ini menempatkan Indonesia di peringkat ke 6, capaian kesetaraan gender Indonesia masih rendah dibandingkan negara-negara ASEAN dan dunia. Indonesia merupakan negara yang menggunakan IPM dan IPG untuk mengukur keberhasilan membangun kualitas hidup manusia. Pentingnya pembangunan kualitas hidup untuk menghadapi berbagai tantangan dan perubahan lingkungan secara global maka perlu dilakukan penelitian yang bertujuan untuk mengetahui faktor-faktor yang mempengaruhi IPM dan IPG di Indonesia dengan analisis statistika yang melibatkan variabel respon dan variabel prediktor.

Penelitian sebelumnya berkaitan dengan indeks pembangunan manusia di Indonesia periode 20082012 menggunakan regresi data panel (Bhakti, 2012). Analisis faktor yang mempengaruhi IPG dengan menggunakan regresi probit (Fitarisca, 2014). Pada penelitian sebelumnya model regresi data panel merupakan gabungan antara data cross-section dan data time series dengan skala pengukuran kontinu. Sementara regresi probit merupakan model dengan variabel respon univariat yang memiliki skala pengukuran kategorik. Kasus khusus apabila data tidak memenuhi asumsi maka dapat diselesaikan dengan model regresi probit. Berdasarkan penelitian tersebut penelitian pada umumnya banyak menggunakan variabel respon univariat, sehingga faktor yang diperoleh hanya berfokus pada satu respon padahal jika memodelkan dengan variabel respon lebih dari satu yang memiliki hubungan satu sama lain akan mendapat hasil yang baik.

Berdasarkan uraian tersebut pendekatan model yang digunakan adalah model regresi probit biner bivariat yang merupakan pengembangan dari regresi probit jika terdapat dua variabel respon biner dengan asumsi ada hubungan yang signifikan antara kedua variabel respon. Model probit biner adalah bentuk lain dari regresi logistik biner dengan fungsi link mengikuti distribusi normal, selain itu model probit biner menggunakan pendekatan Cumulative Distribution Function (CDF), dimana pendekatan ini mampu mengatasi Linier Probability Models (LPM).

\section{Metodologi}

\subsection{Sumber Data dan Variabel Penelitian}




\section{Lendy Dinda Ayu Safitri, Elvira Mustikawati Putri Hermanto, Artanti Indrasetianingsih}

Sumber data yang digunakan dalam penelitian ini adalah data sekunder dari Badan Pusat Statistika (BPS), diambil dari publikasi maupun hasil survei. Data publikasi yang digunakan dimuat dalam buku Indeks Pembangunan Manusia 2017 (BPS, 2017) dan Statistika Indonesia 2018 (BPS, 2018). Pada buku publikasi tersebut digunakan data penelitian tahun 2017 dengan unit observasi penelitian adalah 34 provinsi yang ada di Indonesia tahun 2017. Variabel respon yang digunakan dalam penelitian ini adalah IPM dan IPG. Variabel prediktor yang diduga berpengaruh yaitu Jumlah Perempuan Menjadi PNS $X_{1}$, Persentase Angka Partisipasi Sekolah SMA/sederajat $X_{2}$, Produk Domestik Regional Bruto (PDRB) $X_{3}$, dan Persentase Tingkat Partisipasi Angkatan Kerja (TPAK) $X_{4}$. IPM dan IPG dikelompokkan menjadi dua kategori

Tabel 1. PengelompokkanVariabel Penelitian

\begin{tabular}{|c|c|c|}
\hline Indikator & IPM & IPG \\
\hline Kategori 0 & $60<\mathrm{IPM} \leq 70$ & $\mathrm{IPG} \leq 90$ \\
\hline Kategori 1 & $70<\mathrm{IPM} \leq 80$ & $\mathrm{IPG}>90$ \\
\hline
\end{tabular}

\subsection{Metode Penelitian}

Langkah analisis yang digunakan dalam penelitian ini adalah sebagai berikut:

1. Memodelkan serta IPM dan IPG dengan regresi probit biner bivariat. Adapun langkahlangkahnya sebagai berikut:

1) Membuat tabel kontingensi antara IPM dan IPG.

2) Melihat ada hubungan antara variabel respon yaitu $Y_{1}$ dan $Y_{2}$ dengan menggunakan uji chisquare.

3) - jika terdapat hubungan antara variabel $Y_{1}$ dan $Y_{2}$ dengan menggunakan regresi probit biner bivariat.

- Jika tidak terdapat hubungan antara variabel $Y_{1}$ dan $Y_{2}$ dengan menggunakan regresi probit biner univariat.

4) Melakukan pengujian parameter probit biner secara simultan.

5) Melakukan pengujian parameter probit biner secara parsial.

6) Meregresikan kembali variabel respon dan variabel prediktor yang signifikan pada model $\widehat{y_{1}^{*}}$ atau $\widehat{y_{2}^{*}}$. Pemilihan model dengan menggunakan metode backward elimination.

7) Menghitung nilai kebaikan model dengan menggunakan kriteria AIC, BIC.

8) Menghitung ketepatan klasifikasi dari model terbaik.

2. Menginterpretasi IPM dan IPG model terbaik dengan mengambil contoh salah satu provinsi di Indonesia.

\section{Hasil dan Pembahasan}

\subsection{Deskripsi IPM dan IPG di Indonesia serta Faktor-faktor yang Diduga Berpengaruh}

Berdasarkan Tabel 2 IPM dengan kategori 0 merupakan nilai IPM yang termasuk Status Menengah Bawah sebanyak 19 provinsi atau 55,9\%, sedangkan untuk kategori 1 merupakan nilai IPM yang termasuk Status Menengah Atas sebanyak 15 provinsi atau 44,1\%. Dan IPG dengan kategori 0 merupakan nilai IPG yang termasuk status dibawah rata-rata sebanyak 14 provinsi atau $41,2 \%$, sedangkan untuk kategori 1 merupakan nilai IPG yang termasuk status diatas rata-rata sebanyak 20 provinsi atau $58,8 \%$. Hal itu sesuai dengan konsep pembangunan manusia bahwa jika nilai IPM tinggi maka IPG juga akan tinggi begitu sebaliknya. 


\section{Lendy Dinda Ayu Safitri, Elvira Mustikawati Putri Hermanto, Artanti Indrasetianingsih}

Gambaran kategori IPM dan IPG di Indonesia sebagai berikut:

Tabel 2. Deskriptif Variabel IPM dan IPG

\begin{tabular}{|c|c|c|c|}
\hline Variabel & Kategori & Frekuensi & Persen \\
\hline \multirow{2}{*}{ IPM } & 0 & 19 & $55,9 \%$ \\
\cline { 2 - 4 } & 1 & 15 & $44,1 \%$ \\
\hline \multirow{2}{*}{ IPG } & 0 & 14 & $41,2 \%$ \\
\cline { 2 - 4 } & 1 & 20 & $58,8 \%$ \\
\hline
\end{tabular}

Tabel 3. Deskriptif Variabel IPM dan IPG terhadap variabel respon

\begin{tabular}{|c|c|r|r|r|r|}
\hline \multicolumn{2}{|c|}{} & \multicolumn{2}{c|}{ Kategori 0 } & \multicolumn{2}{c|}{ Kategori 1 } \\
\cline { 3 - 7 } \multicolumn{2}{|c|}{} & MEAN & \multicolumn{1}{c|}{ ST.DEV } & MEAN & \multicolumn{1}{c|}{ ST.DEV } \\
\hline \multirow{4}{*}{ IPM } & (X1) & 35119,947 & 19493,945 & 91048,933 & 67563,219 \\
\cline { 2 - 6 } & $(\mathrm{X} 2)$ & 72,121 & 4,774 & 76,113 & 6,447 \\
\cline { 2 - 6 } & $(\mathrm{X} 3)$ & 126968599,184 & 90865841,888 & 755325597,271 & 714551988,020 \\
\cline { 2 - 6 } & $(\mathrm{X} 4)$ & 70,037 & 2,828 & 68,524 & 5,552 \\
\hline \multirow{5}{*}{ IPG } & $(\mathrm{X} 1)$ & 40647,286 & 46536,046 & 73197,550 & 56066,308 \\
\cline { 2 - 6 } & $(\mathrm{X} 2)$ & 71,319 & 5,431 & 75,677 & 5,571 \\
\cline { 2 - 6 } & $(\mathrm{X} 3)$ & 303695908,076 & 456600865,643 & 474527231,525 & 631116264,382 \\
\cline { 2 - 6 } & $(\mathrm{X} 4)$ & 68,749 & 3,142 & 69,805 & 4,930 \\
\hline
\end{tabular}

Berdasarkan Tabel 3 diketahui bahwa provinsi dengan tingkat IPM kategori status menengah atas memiliki perempuan menjadi PNS sebanyak 91048,933 orang, rata-rata Angka Pertisipasi Sekolah SMA/sederajat sebanyak 76,1 persen, rata-rata PDRB sebanyak 755325597,271 juta rupiah, dan ratarata Tingkat Partisipasi Angkatan Kerja sebanyak 68,5 persen. Untuk Provinsi dengan tingkat IPM kategori status menengah bawah memiliki perempuan menjadi PNS sebanyak 35119,947 orang, ratarata Angka Pertisipasi Sekolah SMA/sederajat sebanyak 72,1 persen, rata-rata PDRB sebanyak 126968599,184 juta rupiah, dan rata-rata Tingkat Partisipasi Angkatan Kerja sebanyak 70 persen. Sedangkan IPG kategori status diatas rata-rata memiliki perempuan menjadi PNS sebanyak 73197,550 orang, rata-rata Angka Pertisipasi Sekolah SMA/sederajat sebanyak 75,6 persen, rata-rata PDRB sebanyak 474527231,525 juta rupiah, dan rata-rata Tingkat Partisipasi Angkatan Kerja sebanyak 69,8 persen. Untuk IPG kategori status dibawah rata-rata memiliki perempuan menjadi PNS sebanyak 40647,286 orang, rata-rata Angka Pertisipasi Sekolah SMA/sederajat sebanyak 71 persen, rata-rata PDRB sebanyak 303695908,076 juta rupiah, dan rata-rata Tingkat Partisipasi Angkatan Kerja sebanyak 68,7 persen. 


\section{Lendy Dinda Ayu Safitri, Elvira Mustikawati Putri Hermanto, Artanti Indrasetianingsih}

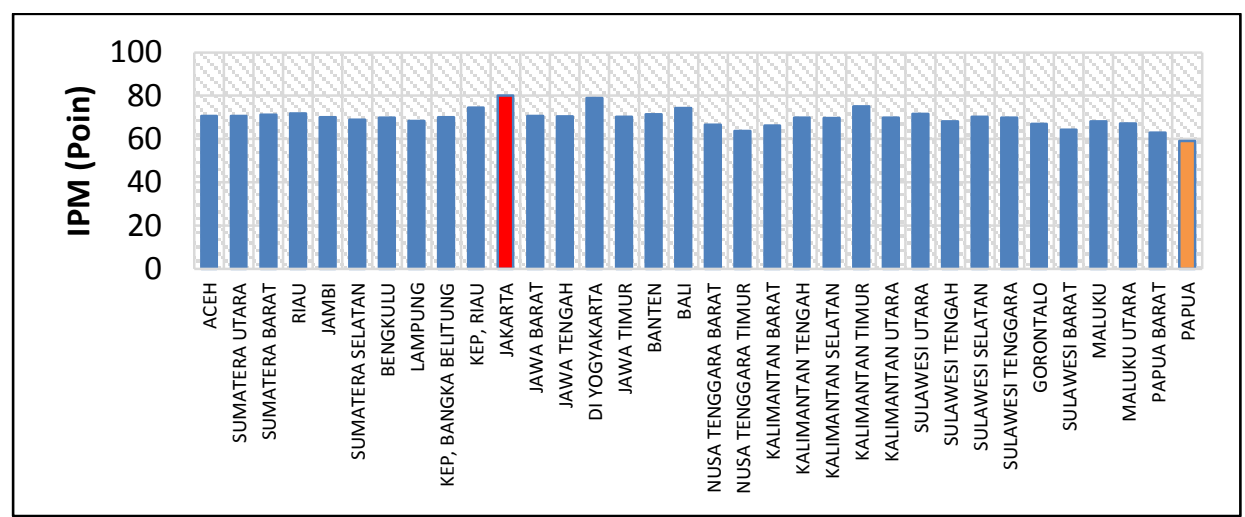

Gambar 1. IPM Tahun 2017 Menurut Provinsi (Sumber : BPS, 2017)

Gambar 1 menjelaskan bahwa IPM di Indonesia tertinggi adalah Provinsi Jakarta dengan nilai sebesar 80,06 dan provinsi dengan IPM terendah yaitu Papua sebesar 59,09. Rata-rata IPM di Indonesia yaitu sebesar 69,7 persen. Hal tersebut terjadi dapat disebabkan kurang meratanya pembangunan yang dilaksanakan oleh pemerintah.

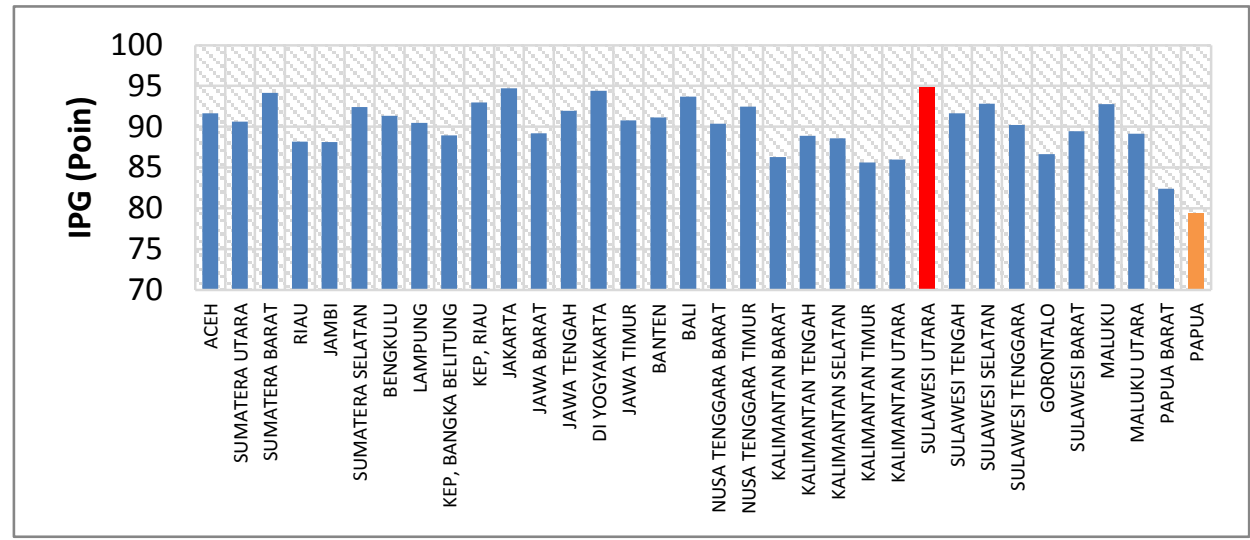

Gambar 2. IPG Tahun 2017 Menurut Provinsi (Sumber : BPS, 2017)

Gambar 2 menjelaskan bahwa provinsi dengan IPG tertinggi di Indonesia yaitu Sulawesi Utara sebesar 94,78 dan provinsi dengan IPG terendah yaitu Papua sebesar 79,38. Rata-rata IPG di Indonesia yaitu sebesar 90 persen. Secara umum dapa dilihat masih banyak IPG yang termasuk kategori dibawah rata-rata.

\subsection{Pemodelan IPM dan IPG Menggunakan Regresi Probit Biner Bivariat}

Model regresi probit biner bivariat antara dua variabel respon dengan syarat harus dependen (ada hubungan antar variabel respon). Analisis yang digunakan untuk mengetahui dependensi antar variabel respon yaitu dengan uji chi-square.

Tabel 4. Tabel Kontingensi Frekuensi IPM dan IPG

\begin{tabular}{|c|l|c|c|c|}
\hline \multicolumn{2}{|c|}{} & \multicolumn{2}{c|}{ IPG } & \multirow{2}{*}{ Total } \\
\cline { 3 - 5 } \multicolumn{2}{|c|}{} & 0 & 1 & 19 \\
\hline \multirow{2}{*}{0} & Jumlah & 11 & 8 & 19 \\
\cline { 3 - 5 } & Persentase & $32,4 \%$ & $23,5 \%$ & $55,9 \%$ \\
\hline
\end{tabular}




\section{Lendy Dinda Ayu Safitri, Elvira Mustikawati Putri Hermanto, Artanti Indrasetianingsih}

\begin{tabular}{|c|l|l|c|c|c|}
\hline \multirow{3}{*}{ IPM } & & Ekspektasi & 7,8 & 11,2 & \\
\cline { 2 - 6 } & \multirow{3}{*}{1} & Jumlah & 3 & 12 & 15 \\
\cline { 3 - 6 } & Persentase & $8,8 \%$ & $35,3 \%$ & $44,1 \%$ \\
\cline { 3 - 6 } & & Ekspektasi & 6,2 & 8,8 & \\
\hline \multirow{2}{*}{ Total } & Jumlah & 14 & 20 & 34 \\
\cline { 3 - 6 } & Presentase & $41,2 \%$ & $58,8 \%$ & $100 \%$ \\
\hline
\end{tabular}

Berdasarkan Tabel 4 persentase IPM dan IPG di Indonesia dapat dilihat secara keseluruhan. Persentase tertinggi 35,3 persen yaitu provinsi dengan IPM kategori 1 dan IPG kategori 1 . Hal tersebut dapat diartikan bahwa 35,3 persen provinsi di Indonesia memiliki IPM kategori menengah atas dan IPG kategori diatas rata-rata. Uji yang digunakan untuk mengetahui hubungan antar keduanya menggunakan uji chi-square. Berdasarkan tabel 4.4 diperoleh nilai dari $P$-value $=$ $0,026<\alpha(0,05)$, maka keputusan adalah tolak $H_{0}$ artinya antara variabel IPM dan IPG di Indonesia saling dependen (ada hubungan antara IPM dan IPG).

\subsubsection{Pemeriksaan Multikolinearitas}

Adanya keeratan hubungan antar variabel prediktor ditunjukkan ketika nilai VIF yang lebih dari 10. Tabel 5 menunjukkan tidak ada multikolinearitas antara variabel prediktor. Hal ini ditunjukkan dengan nilai VIF kurang dari 10

Tabel 5. Pemeriksaan Multikolinearitas Nilai VIF

\begin{tabular}{|c|c|}
\hline Variabel & VIF \\
\hline$X_{1}$ & 1.0341 \\
\hline$X_{2}$ & 1,0940 \\
\hline$X_{3}$ & 1.1350 \\
\hline$X_{4}$ & 1.0152 \\
\hline
\end{tabular}

Selain menggunakan VIF, untuk menguji multikolinearitas dapat melihat matriks korelasi dari variabel bebas, jika nilai korelasi > 0,8 maka terdapat hubungan yang signifikan (Gujarati, 2003). Tabel 6 menunjukkan tidak ada multikolinearitas antara variabel prediktor karena nilai korelasi kurang dari 0,8 .

Tabel 6. Pemeriksaan Multikolinearitas Nilai Korelasi

\begin{tabular}{|l|r|r|r|r|}
\hline & \multicolumn{1}{|c|}{ X1 } & \multicolumn{1}{c|}{ X2 } & \multicolumn{1}{c|}{ X3 } & \multicolumn{1}{c|}{ X4 } \\
\hline X1 & 1 & $-0,231$ & $-0,029$ & 0,614 \\
\hline X2 & $-0,231$ & 1 & 0.17 & $-0,221$ \\
\hline X3 & $-0,029$ & 0,17 & 1 & 0,505 \\
\hline X4 & 0,614 & $-0,221$ & 0,505 & 1 \\
\hline
\end{tabular}

\subsubsection{Pengujian Model Probit Biner Bivariat secara Simultan}




\section{Lendy Dinda Ayu Safitri, Elvira Mustikawati Putri Hermanto, Artanti Indrasetianingsih}

\section{a. Pengujian Model Probit Biner Bivariat secara Simultan}

Hipotesis pengujian signifikansi parameter secara simultan adalah:

$H_{0}: \beta_{11}=\beta_{12}=\cdots=\beta_{1 p}=\beta_{21}=\beta_{22}=\cdots=\beta_{2 p}=0$

$H_{1}$ : paling sedikit ada satu $\beta_{r s} \neq 0$, dengan $r=1,2$ dan $s=1,2,3, \ldots, p$

Berdasarkan pemodelan diperoleh hasil uji secara simultan yaitu nilai Likelihood Rasio Test $\left(G^{2}\right)$ sebesar 45,55 dan pvalue $=0,000<\alpha(0,05)$, maka keputusan tolak $H_{0}$, sehingga kesimpulannya adalah terdapat minimal satu variabel prediktor yang signifikan terhadap salah satu variabel respon.

\section{b. Pengujian Model Probit Biner Bivariat secara Parsial}

Berikut ini adalah koefisien dan pvalue pada masing-masing prediktor.

Tabel 7. Koefisien dan pvalue Masing-masing Parameter Model Probit Biner Bivariat pada IPM dan IPG

\begin{tabular}{|c|c|c|c|c|}
\hline \multirow{2}{*}{ Variabel } & \multicolumn{2}{|c|}{ IPM } & \multicolumn{2}{c|}{ IPG } \\
\cline { 2 - 5 } & Estimasi & pvalue & Estimasi & pvalue \\
\hline Konstanta & $-17,88614$ & 0,076 & $-14,3391$ & 0,086 \\
\hline$X_{1}$ & $-0,0000132$ & 0,732 & 0,0000202 & 0,032 \\
\hline$X_{2}$ & 0,3208683 & 0,018 & 0,1345926 & 0,017 \\
\hline$X_{3}$ & $1,19 \mathrm{e}-08$ & 0,179 & $-6,64 \mathrm{e}-10$ & 0,371 \\
\hline$X_{4}$ & $-0,1229879$ & 0,396 & 0,0549567 & 0,517 \\
\hline
\end{tabular}

Pemodelan pertama dilakukan dengan meregresikan semua variabel prediktor dengan variabel respon. Hasil pemodelan secara lengkap adalah sebagai berikut:

$\hat{y}_{1}^{*}=-17,88614-0,0000132 x_{1}+0,3208683 x_{2}+1,19 \mathrm{e}-08 x_{3}-0,1229879 x_{4}$ $\hat{y}_{2}^{*}=-14,3391+, .0000202 x_{1}+0,1345926 x_{2}-6,64 \mathrm{e}-10 x_{3}+0,0549567 x_{4}$

Berdasarkan Tabel 7 hasil uji model probit biner bivariat, terdapat satu variabel prediktor yang tidak signifikan terhadap variabel respon. Variabel prediktor yang memiliki pvalue paling besar adalah variabel $X_{4}$ yaitu Tingkat Partisipasi Angkatan Kerja (TPAK), sehingga hal yang dilakukan selanjutnya adalah mengeliminasi variabel tersebut.

\subsubsection{Pengujian Model Probit Biner Bivariat secara Simultan (Mengeliminasi $X_{4}$ )}

\section{a. Pengujian Model Probit Biner Bivariat secara Simultan (Mengeliminasi $\boldsymbol{X}_{\mathbf{4}}$ )}

Model $\hat{y}_{1}^{*}$ dan $\hat{y}_{2}^{*}$ diperoleh hasil uji secara simultan yaitu nilai Likelihood Rasio Test $\left(G^{2}\right)$ sebesar 43,53 dan pvalue $=0,000<\alpha(0,05)$, maka keputusan tolak $H_{0}$, sehingga kesimpulannya adalah terdapat minimal satu variabel prediktor yang signifikan terhadap salah satu variabel respon.

\section{b. Pengujian Signifikansi Parameter secara Parsial (Mengeliminasi $\boldsymbol{X}_{4}$ )}

Selanjutnya yaitu dilakukan uji secara parsial dengan mengeliminasi variabel $X_{4}$ karena variabel $X_{4}$ adalah variabel yang paling tidak signifikan ditunjukkan oleh nilai pvalue (Tabel 7), berikut ini adalah koefisien dan pvalue pada masing-masing prediktor.

Tabel 8. Koefisien dan pvalue Masing-masing Parameter Model Probit Biner Bivariat pada IPM dan IPG (Mengeliminasi $X_{4}$ )

\begin{tabular}{|l|l|l|}
\hline & IPM & IPG \\
\hline
\end{tabular}




\section{Lendy Dinda Ayu Safitri, Elvira Mustikawati Putri Hermanto, Artanti Indrasetianingsih}

\begin{tabular}{|c|c|c|c|c|}
\hline Variabel & Estimasi & pvalue & Estimasi & pvalue \\
\hline Konstanta & $-23,48978$ & 0,001 & $-9,744747$ & 0,009 \\
\hline$X_{1}$ & 0,0000217 & 0,151 & 0,00002 & 0,038 \\
\hline$X_{2}$ & 0,273787 & 0,001 & 0,1242597 & 0,010 \\
\hline$X_{3}$ & $5,47 \mathrm{e}-09$ & 0,007 & $-7,98 \mathrm{e}-10$ & 0,270 \\
\hline
\end{tabular}

Berdasarkan Tabel 8 terdapat variabel prediktor yang signifikan minimal terhadap salah satu variabel respon, sehingga metode backward elimination berhenti dan dihasilkan model probit biner bivariat dengan melibatkan tiga variabel prediktor yaitu Jumlah Perempuan Menjadi PNS, Persentase Angka Partisipasi Sekolah SMA/sederajat, dan Produk Domestik Regional Bruto (PDRB).

Hasil pemodelan dengan mengeliminasi variabel $X_{4}$ adalah sebagai berikut:

$\hat{y}_{1}^{*}=-23,48978+0,0000217 x_{1}+0,273787 x_{2}+5,47 \mathrm{e}-09 x_{3}$

$\hat{y}_{2}^{*}=-9,744747+0,00002 x_{1}+0,1242597 x_{2}-7,98 \mathrm{e}-10 x_{3}$

Berdasarkan model $\hat{y}_{1}^{*}$ di atas dimana setiap satu peningkatan nilai $x_{1}$, akan meningkat nilai $\mathrm{Z}$ score sebanyak 0,0000217 . Sedangkan untuk model $\hat{y}_{2}^{*}$ sama setiap satu peningkatan nilai $x_{1}$, akan meningkat nilai $\mathrm{Z}$ score sebanyak 0,00002.

\subsubsection{Pengujian Kriteria Kebaikan Model}

Uji yang dilakukan untuk mengetahui apakah model yang terbentuk sudah cukup baik pada model regresi probit biner bivariat yaiu dengan Akaike Information Criterion (AIC) dan Bayesian Information Criterion (BIC). Jika diperoleh nilai AIC dan BIC paling kecil maka model yang terbentuk semakin baik. Berikut ini adalah hasil pemilihan model terbaik dengan kriteria AIC dan BIC.

Tabel 9. Rangkuman Nilai AIC dan BIC

\begin{tabular}{|c|c|c|}
\hline Model & AIC & BIC \\
\hline$X_{1}, X_{2}, X_{3}, X_{4}$ & 61,99035 & 77,25396 \\
\hline $\boldsymbol{X}_{\mathbf{1}}, \boldsymbol{X}_{\mathbf{2}}, \boldsymbol{X}_{\mathbf{3}}$ & $\mathbf{6 0 , 0 0 7 6 8}$ & $\mathbf{7 2 , 2 1 8 5 7}$ \\
\hline
\end{tabular}

Berdasarkan Tabel 9 nilai AIC dan BIC terkecil adalah model dengan melibatkan tiga variabel prediktor yaitu Persentase Perempuan Menjadi PNS (X1), Persentase Angka Partisipasi Sekolah SMA/sederajat (X2), dan Produk Domestik Regional Bruto (PDRB) (X3). Hasil pemilihan model berdasarkan AIC dan BIC tersebut sesuai dengan pemilihan model terbaik menggunakan metode backward elimination.

\subsubsection{Analisis dan Interpretasi Model Regresi Probit Biner Bivariat}

Model terbaik probit biner bivariat yang terbentuk yaitu $\hat{y}_{1}^{*}$ dan $\hat{y}_{2}^{*}$ diubah menjadi persamaan sebagai $z_{1}$ dan $z_{2}$ sebagai berikut:

$z_{1}=\hat{y}_{1}^{*}=-23,48978+0,0000217 x_{1}+0,273787 x_{2}+5,47 \mathrm{e}-09 x_{3}$

$z_{2}=\hat{y}_{2}^{*}=-9,744747+0,00002 x_{1}+0,1242597 x_{2}-7,98 \mathrm{e}-10 x_{3}$

Dari persamaan tersebut misalkan pada suatu provinsi di Indonesia yaitu Jawa Timur yang memiliki Perempuan Menjadi PNS (X1) sebesar 213.868 orang, Persentase Angka Partisipasi Sekolah SMA/sederajat (X2) sebesar 71,51 persen, dan Produk Domestik Regional Bruto (PDRB) (X3) sebesar Rp 2.012.917.991.960. Nilai $z_{1}$ dan $z_{2}$ untuk provinsi Jawa Timur adalah sebagai berikut: 


\section{Lendy Dinda Ayu Safitri, Elvira Mustikawati Putri Hermanto, Artanti Indrasetianingsih}

$$
\begin{aligned}
& z_{1}=-23,48978+0,0000217(213868)+0,273787(71,51)+5,47 \mathrm{e}-09(2012917991,960) \\
& z_{2}=-9,744747+0,00002(213868)+0,1242597(70,51)-7,98 \mathrm{e}-10(2012917991,960)
\end{aligned}
$$

Maka dari nilai $z_{1}$ dan $z_{2}$ untuk provinsi Jawa Timur adalah $z_{1}$ sebesar 0,8483386 dan $z_{2}$ sebesar -1,09253738. Nilai probabilitas bersama $z_{1}$ dan $z_{2}$ dari model probit biner bivariat adalah sebagai berikut:

$$
\begin{aligned}
\widehat{\mathrm{P}}_{11} & =1-\Phi\left(\mathrm{z}_{1}\right)-\Phi\left(\mathrm{z}_{2}\right)+\Phi\left(\mathrm{z}_{1}, \mathrm{z}_{2}\right) \\
& =1-\Phi(0,8483386)-\Phi(-1,09253738)+\Phi(0,8483386 ;-1,09253738) \\
& =1-0,8018753-0,80157786+0,6744812 \\
& =0,07102804 \\
\widehat{\mathrm{P}}_{10} & =\Phi\left(\mathrm{z}_{2}\right)-\Phi\left(\mathrm{z}_{1}, \mathrm{z}_{2}\right) \\
& =\Phi(-1,09253738)-\Phi(0,8483386 ;-1,09253738) \\
& =0,80157786-0,6744812 \\
& =0,12709667 \\
\widehat{\mathrm{P}}_{01} & =\Phi\left(\mathrm{z}_{1}\right)-\Phi\left(\mathrm{z}_{1}, \mathrm{z}_{2}\right) \\
& =\Phi(0,8483386)-\Phi(0,8483386 ;-1,09253738) \\
& =0,8018753-0,6744812 \\
& =0,1273941 \\
\widehat{\mathrm{P}}_{00}= & \Phi\left(\mathrm{z}_{1}, \mathrm{z}_{2}\right) \\
& =\Phi(0,8483386 ;-1,09253738) \\
& =0,6744812
\end{aligned}
$$

Probabilitas provinsi Jawa Timur yang memiliki IPM dan IPG termasuk kategori rendah yaitu sebesar 0,6744812. Nilai probabilitas tersebut menunjukkan bahwa provinsi Jawa Timur memiliki peluang dengan IPM dan IPG rendah yang sangat tinggi, sehingga perlu adanya perlakuan khusus di provinsi Jawa Timur untuk menangani masalah IPM dan IPG. Probabilitas salah satu variabel berkategori IPM tinggi dan IPG rendah di Provinsi Jawa Timur yaitu sebesar 0,12709667 dan 0,1273941, hal itu sesuai dengan konsep bahwa jika nilai IPM rendah maka nilai IPG akan tinggi, begitupun sebailknya.

\subsubsection{Efek Marginal Masing-Masing Variabel Prediktor}

Besar pengaruh setiap provinsi dari masing-masing variabel prediktor terhadap variabel respon dengan mengasumsikan variabel lainnya konstan dari model regresi probit biner bivariat yang diperoleh dapat dilihat dari efek marginalnya jika:

$\boldsymbol{x}_{\boldsymbol{i}}=\left(\begin{array}{llll}1 & x_{1 i} & x_{2 i} & x_{3 i}\end{array}\right)$

$\hat{\beta}_{1}=\left(\begin{array}{llll}\hat{\beta}_{10} & \hat{\beta}_{11} & \hat{\beta}_{12} & \hat{\beta}_{13}\end{array}\right)^{T}$

$\hat{\beta}_{2}=\left(\begin{array}{llll}\hat{\beta}_{20} & \hat{\beta}_{21} & \hat{\beta}_{22} & \hat{\beta}_{23}\end{array}\right)^{T}$

maka persamaan yang digunakan untuk memperoleh nilai marginalnya adalah:

Dari persamaan sebagai contoh yaitu provinsi Jawa Timur diperoleh nilai marginal dari masingmasing variabel prediktor yang signifikan adalah sebagai berikut:

a. Efek marginal dari variabel Persentase Perempuan Menjadi PNS $\left(x_{1}\right)$

$$
\frac{\partial \hat{P}_{11}}{\partial x_{i}}=0,3248925
$$




\section{Lendy Dinda Ayu Safitri, Elvira Mustikawati Putri Hermanto, Artanti Indrasetianingsih}

$$
\begin{aligned}
& \frac{\partial \hat{P}_{10}}{\partial x_{i}}=-2,791863 \mathrm{e}-06 \\
& \frac{\partial \hat{P}_{01}}{\partial x_{i}}=-2,323665 \mathrm{e}-06 \\
& \frac{\partial \hat{P}_{00}}{\partial x_{i}}=3,341903 \mathrm{e}-07
\end{aligned}
$$

Hasil yang diperoleh dari perhitungan efek marginal untuk variabel Persentase Perempuan Menjadi PNS $\left(x_{1}\right)$ sebesar 0,3248925 yang berarti bahwa setiap kenaikan $\left(x_{1}\right)$ satu satuan akan menaikan probabilitas provinsi Jawa Timur IPM menengah atas dan IPG diatas rata-rata sebesar 0,3248925 .

b. Efek marginal dari variabel Persentase Angka Partisipasi Sekolah SMA/sederajat $\left(x_{2}\right)$

$$
\begin{aligned}
& \frac{\partial \hat{P}_{11}}{\partial x_{i}}=0,03101755 \\
& \frac{\partial \hat{P}_{10}}{\partial x_{i}}=-0,04519855 \\
& \frac{\partial \hat{P}_{01}}{\partial x_{i}}=-0,003604868 \\
& \frac{\partial \hat{P}_{00}}{\partial x_{i}}=0,02992906
\end{aligned}
$$

Hasil yang diperoleh dari perhitungan efek marginal untuk variabel Persentase Angka Partisipasi Sekolah SMA/sederajat $\left(x_{3}\right)$ sebesar 0,03101755 yang berarti bahwa setiap penurunan $\left(x_{3}\right)$ satu satuan akan menaikan probabilitas provinsi Jawa Timur IPM menengah atas dan IPG diatas rata-rata sebesar 0,03101755.

c. Efek marginal dari Produk Domestik Regional Bruto (PDRB) $\left(x_{3}\right)$

$$
\begin{aligned}
& \frac{\partial \hat{P}_{11}}{\partial x_{i}}=3,642317 \mathrm{e}-10 \\
& \frac{\partial \hat{P}_{10}}{\partial x_{i}}=-1,158492 \mathrm{e}-09 \\
& \frac{\partial \hat{P}_{01}}{\partial x_{i}}=5,86578 \mathrm{e}-10 \\
& \frac{\partial \hat{P}_{00}}{\partial x_{i}}=1,256554 \mathrm{e}-09
\end{aligned}
$$

Hasil yang diperoleh dari perhitungan efek marginal untuk variabel Produk Domestik Regional Bruto (PDRB). $\left(x_{3}\right)$ sebesar 3,642317e -10 yang berarti bahwa setiap kenaikan $\left(x_{3}\right)$ satu satuan akan menaikan probabilitas provinsi Jawa Timur IPM menengah atas dan IPG diatas rata-rata sebesar $3,642317 \mathrm{e}-10$.

\subsubsection{Ketepatan Klasifikasi}

Ketepatan pendugaan model dari suatu analisi regresi probit biner bivariat dapat diketahui melalui tabel klasifikasi dengan menggunakan nilai APPER yaitu nilai dari kecilnya persentase prediksi yang salah dalam pengklasifikasian, sedangkan untuk menghitung ketepatan klasifikasi yaitu 


\section{Lendy Dinda Ayu Safitri, Elvira Mustikawati Putri Hermanto, Artanti Indrasetianingsih}

1 - APPER. Berdasarkan model terbaik yang terpilih diperoleh prediksi ketepatan klasifikasi sebagai berikut:

Tabel 10. Ketepatan Klasifikasi

\begin{tabular}{|c|c|c|c|c|c|c|}
\hline & \multicolumn{4}{|c|}{ Prediksi } & \multirow[b]{2}{*}{ Total } \\
\hline & & $Y_{00}$ & $Y_{01}$ & $Y_{10}$ & $Y_{11}$ & \\
\hline \multirow{4}{*}{ Observasi } & $Y_{00}$ & 10 & 1 & 0 & 0 & 11 \\
\hline & $Y_{01}$ & 1 & 7 & 0 & 0 & 8 \\
\hline & $Y_{10}$ & 0 & 0 & 0 & 3 & 3 \\
\hline & $Y_{11}$ & 1 & 1 & 1 & 9 & 12 \\
\hline \multicolumn{2}{|c|}{ Total } & 12 & 9 & 1 & 12 & 34 \\
\hline
\end{tabular}

Berdasarkan Tabel 10 dapat diketahui bahwa ketepatakan klasifikasi yang diperoleh sebesar 0,765 atau 76,5 persen yang artinya ketepatan mengklasifikasikan provinsi sesuai klasifikasi aktual sebanyak 26 provinsi yang ada di Indonesia, artinya terdapat kesalahan mengkategorikan provinsi sebanyak 8 provinsi

\section{Simpulan dan Saran}

Berdasarkan hasil pemodelan regresi probit biner bivariat terbaik dengan metode backward elimination diperoleh variabel prediktor yang signifikan sebanyak tiga variabel. Variabel tersebut adalah Jumlah Perempuan Menjadi PNS $\left(x_{1}\right)$, Persentase Angka Partisipasi Sekolah SMA/sederajat $\left(x_{2}\right)$, dan Produk Domestik Regional Bruto $(\mathrm{PDRB})\left(x_{3}\right)$ ketepatan klasifikasi yang dihasilkan model regresi probit biner bivariat sebesar 76,5 persen.

Interpretasi model $\hat{y}_{1}^{*}$ yang terbentuk adalah dimana setiap satu peningkatan nilai Persentase Perempuan Menjadi PNS $\left(x_{1}\right)$, akan meningkat nilai $\mathrm{Z}$ score sebanyak 0,0000217 , dimana setiap satu peningkatan nilai Persentase Angka Partisipasi Sekolah SMA/sederajat $\left(x_{2}\right)$, akan meningkat nilai $\mathrm{Z}$ score sebanyak 0,273787, dan dimana setiap satu peningkatan nilai Produk Domestik Regional Bruto $(\mathrm{PDRB})\left(x_{3}\right)$, akan meningkat nilai $\mathrm{Z}$ score sebanyak $5,47 \mathrm{e}-09$. Sedangkan untuk model $\hat{y}_{2}^{*}$ sama setiap satu peningkatan nilai Persentase Perempuan Menjadi PNS $\left(x_{1}\right)$, akan meningkat nilai $\mathrm{Z}$ score sebanyak 0,00002, dimana setiap satu peningkatan nilai Persentase Angka Partisipasi Sekolah SMA/sederajat $\left(x_{2}\right)$, akan meningkat nilai $Z$ score sebanyak 0,1242597, dan atas dimana setiap satu peningkatan nilai Produk Domestik Regional Bruto $(\mathrm{PDRB})\left(x_{3}\right)$, akan meningkat nilai Z score sebanyak 7,98e - 10 .

Interpretasi dengan mengambil contoh provinsi Jawa Timur diperoleh prediksi probabilitas IPM menengah bawah dan IPG dibawah rata-rata sebesar 0,6744812. Nilai probabilitas tersebut berarti provinsi Jawa Timur berpeluang besar memiliki IPM menengah bawah dan IPG diatas rata-rata. Berdasarkan hasil perhitungan efek marginal yaitu setiap penurunan variabel Perempuan Menjadi PNS $\left(x_{1}\right)$ satu satuan akan menaikan probabilitas provinsi Jawa Timur IPM menengah atas dan IPG diatas rata-rata sebesar 0,3248925 sedangkan setiap Persentase Angka Partisipasi Sekolah SMA/sederajat $\left(x_{2}\right)$ satu satuan akan menaikan probabilitas provinsi Jawa Timur IPM menengah atas dan IPG diatas rata-rata sebesar 0,03101755 dan setiap Produk Domestik Regional Bruto $(\mathrm{PDRB})\left(x_{3}\right)$ satu satuan akan menaikan probabilitas provinsi Jawa Timur IPM menengah atas dan IPG diatas rata-rata sebesar $3,642317 \mathrm{e}-10$ 


\section{Lendy Dinda Ayu Safitri, Elvira Mustikawati Putri Hermanto, Artanti Indrasetianingsih}

Adapun saran yang diberikan penulis yaitu agar pada penelitian selanjutnya hendaknya menambah variabel-variabel lain yang diduga berpengaruh secara signifikan terhadap IPM dan IPG memperoleh ketepatan klasifikasi yang lebih baik.

\section{Daftar Pustaka}

Badan Pusat Statistik, 2016, Indeks pembangunan gender 2016, BPS Indonesia

Badan Pusat Statistik, 2017, Indeks pembangunan manusia 2017, BPS Indonesia

Badan Pusat Statistik, 2017, Produk Domestik Regional Bruto Provinsi-provinsi di Indonesia Menurut Lapangan Usaha 2013-2017, BPS Indonesia

Badan Pusat Statistik, 2018, Laporan Bulanan Data Sosial Ekonomi edisi 92 januari 2018, BPS Indonesia

Badan Pusat Statistik, 2018, Statistik Indonesia 2018, BPS Indonesia

BAPPENAS, 2017, Kebijakan dan Strategi Pembangunan Kesetaraan Gender dan Pemberdayaan Perempuan, Kementrian Perencanaan Pembangunan Nasional dan BAPPENAS, Jakarta

Bhakti, N.A, 2012, Analisis Faktor-Faktor yang Mempengaruhi Indeks Pembangunan Manusia di Indonesia 2008-2012, Skripsi, Universitas Jendral Soedirman,Jawa Tengah

Fitarisca, A.V., 2014, Analisis Faktor-Faktor yang Mempengaruhi Indeks Pembangunan Gender (IPG) Dengan Menggunakan Regresi Probit, Skripsi, Institut Teknologi Sepuluh November, Surabaya

Gujarati, Damodar. 2003.Ekonometrika Dasar. Erlangga. Jakarta.

United Nations Development Programme (UNDP). 1990. Global Human Development Report. Human Resources Department.

United Nation Development Programme (UNDP). 1995. The state of human development. UNDP, NewYork (forth coming in September). 